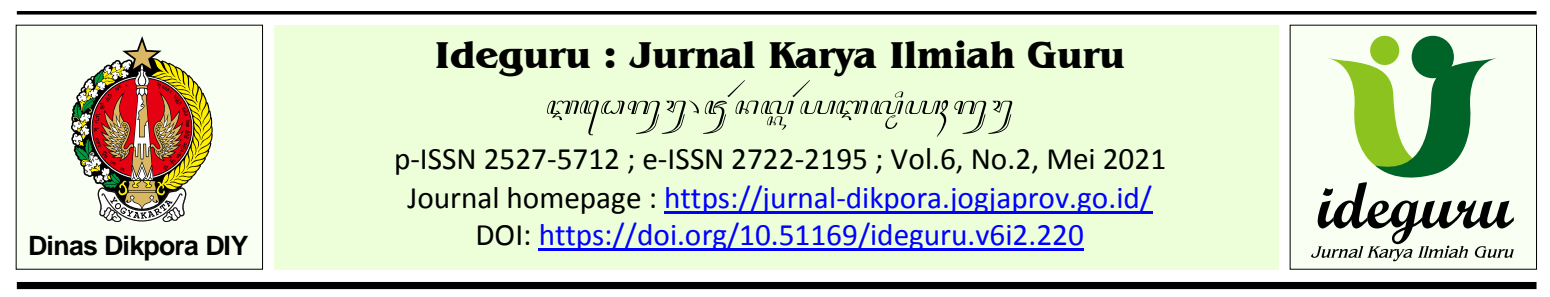

Artikel Penelitian - Naskah dikirim: 03/02/2021 - Selesai revisi: 06/04/2021 - Disetujui: 10/04/2021 - Diterbitkan: 01/05/2021

\title{
Peningkatan Hasil Belajar pada Materi Offering Help Menggunakan Model Snowball Throwing
}

\author{
Endang Sugiharyanti \\ SMK Negeri 1 Ponjong \\ sg.endang@yahoo.com
}

\begin{abstract}
Abstrak: Penelitian ini dalam wujud Penelitian Tindakan Kelas (PTK), sebab terdapat permasalahan yang ditemukan penulis dalam pembelajaran Bahasa Inggris, yaitu persentase siswa yang mendapatkan nilai kurang dari Kriteria Ketuntasan Minimun (KKM) yang ditetapkan 75. Sehingga penulis dengan melaksanakan PTK ini diharapkan dapat tingkatkan hasil belajar peserta didik yang diberi pembelajaran Bahasa Inggris pada materi Offering Help dengan menggunakan model Snowball Throwing. PTK dilakukan di kelas XII TKR A SMK Negeri 1 Ponjong. Peneliti melakukan kegiatan penelitian dengan 2 siklus, diawali dari perencanaan, penerapan, pengamatan, refleksi, serta perbaikan. Dalam kegiatan setiap siklus peneliti melakukannya 2 kali pertemuan. Hasil pengujian menunjukkan bahwa pembelajaran dengan model Snowball Throwing berjalan lebih baik. Hal ini dibuktikan dengan persentase nilai ketuntasan peserta didik mengalami kenaikan $22 \%$ ditunjukkan pada siklus I rata-rata 71 dan pada siklus II rata-rata 78 sementara persentase peserta didik yang mendapat nilai belum tuntas mengalami penurunan. Di akhir penelitian tingkat ketuntasan peserta didik secara klasikal meningkat dari dari $68 \%$ menjadi $90 \%$.
\end{abstract}

Kata Kunci: peningkatan, Snowball Throwing, hasil belajar

\section{Improvement the Result of Learning in the Offering Help Material Using the Snowball Throwing Model}

\begin{abstract}
This research is in the form of Classroom Action Research (CAR), because there are problems that the authors find in learning English, namely the percentage of students who get a score less than the Minimum Completeness Criteria which is set at 75. So that the author by carrying out CAR this is expected to improve the result of students learning who is given English learning in the Offering Help material using the Snowball Throwing model. CAR is conducted in class XII TKR A SMK Negeri 1 Ponjong. Researchers carry out research activities in 2 cycles, starting with planning, implementing, observing, reflecting, and improving. In the activity of each cycle the researcher did 2 meetings. The test results show that learning with the Snowball Throwing model runs better. This is evidenced by the percentage of student completeness values that have increased by $22 \%$, shown in the first cycle an average of 71 and in the second cycle an average of 78, while the percentage of students who received an incomplete score decreased. At the end of the study, the mastery level of students classically increased from $68 \%$ to $90 \%$.
\end{abstract}

Keywords: enhancement, Snowball Throwing, the result of learning

\section{Pendahuluan}

Setiap insan membutuhkan pendidikan sebagai kebutuhan manusia sepanjang hayat dan selalu berubah mengikuti perkembangan zaman. Pendidikan bisa di peroleh di dalam keluarga dan di sekolah. Iklim instruktif kedua tersebut akan memberikan perkembangan positif kepada anak. Seperti yang tertuang di dalam UUD 1945, alasan sekolah umum adalah untuk mengajarkan kehidupan berbangsa. Bahasa Inggris adalah ilmu bahasa untuk mempersiapkan penalaran dasar, dan inovatif yang kuat. Perspektif ini dapat diciptakan melalui pembelajaran bahasa Inggris, karena bahasa Inggris memiliki konstruksi yang kokoh dan jelas serta keterkaitan antara hipotesis dengan tujuan melatih untuk menjadi lebih berbakat, berpikir dan mengungkapkan baik secara lisan dan bentuk tulisan nyata.

Banyak siswa yang tidak senang dan tidak semangat untuk mempelajari Bahasa Inggris, selain bukan bahasa ibu, Bahasa Inggris adalah pelajaran yang dianggap sangat sulit dan menjemukan. Menurunnya semangat belajar dapat juga disebabkan tidak memilih model pembelajaran yang sesuai yang digunakan oleh guru. 
Kebiasaan yang sering terjadi dalam kegiatan belajar Bahasa Inggris antara lain siswa tidak dinamis, tidak berpartisipasi aktif, dan kurang inisiatif. Peserta didik tidak mau bertanya, gagasan maupun pendapat sering tidak muncul. Peserta didik tidak merespon terhadap materi yang disampaikan oleh guru, bahkan guru secara sadar atau tidak sadar hanya menerapkan pembelajaran yang hanya fokus pada guru, pendidik hanya menyampaikan informasi dengan satu cara, dan siswa sebagai penerima manfaat, pencatat dan pembaruan sebagaimana adanya.

Berdasarkan pengamatan pada hari kamis, tanggal 15 Februari 2020, di SMK Negeri Ponjong, guru bahasa Inggris sudah menerapkan metode diskusi kelompok yang tujuannya agar setiap siswa mau menyampaikan pendapat hasil belajarnya. Namun kenyataannya dalam diskusi kelompok tersebut, yang dapat menguasai materi hanya satu dua orang saja, yang lain sebagai pendengar dan pencatat dan apabila ditanya guru tentang hasil diskusinya, siswa tersebut belum bisa meningkatkan hasil belajar siswa. Kelompok tersebut belum dapat menyatukan persepsi sikap siswa terhadap pelajaran bahasa Inggris. Hal ini mempengaruhi hasil belajar siswa, sebagian siswa sudah bersikap perhatian terhadap pelajaran Bahasa Inggris serta mendapatkan skor tinggi, tetapi lebih banyak siswa tidak menunjukkan perhatian terhadap pelajaran Bahasa Inggris serta mendapat nilai Bahasa Inggris sangat rendah. Hal ini terlihat dari laporan hasil pembelajaran semester gasal tahun pelajaran 2019/2020, sebagian siswa telah mendapatkan nilai 75 tetapi masih banyak siswa yang mendapatkan nilai antara 70-74. Padahal KKM nya adalah 75.

Keadaan seperti ini yang menjadi keprihatinan guru, karena Bahasa Inggris adalah satu ilmu bahasa yang melatih berpikir kritis, kreatif dan efektif. Dimana belajar Bahasa Inggris harus mengerti struktur dan hubungan yang solid dan jelas antara teori sehingga kemampuan bahasa dapat dilatih seperti keterampilan berbahasa yang dapat di praktikan baik secara lisan dan dalam bentuk tulisan nyata. Bahasa Inggris adalah dialek asing yang harus dipelajari karena bukan bahasa ibu maka membuat materi bahasa Inggris sulit diterima dan dipahami oleh siswa. Bahasa Inggris merupakan pelajaran yang dianggap sangat sulit dan menjemukan. Akibatnya akan menurunkan hasil belajar peserta didik dalam belajar Bahasa Inggris. Menurut Djamarah (1999) Belajar adalah perkembangan latihan dan semangat untuk melakukan perubahan sebagai keterlibatan individu dengan kolaborasi dengan lingkungan termasuk psikologis, emosional dan psikomotor.

Menurut R. Gagne (1999) Belajar adalah siklus inspirasi informasi, baik berupa keterampilan, dan sikap. Menurut Gagne (1984) belajar adalah interaksi untuk mengubah perilaku sebagai hasil dari pegalaman. Penulis berpendapat bahwa belajar adalah interaksi pembelajaran yang diselesaikan dan diperoleh seseorang pada waktu tertentu menjadikan pengalaman hidup dan menjadi perubahan perilaku menjadi lebih baik.

Sementara hasil belajar dilaksanakan sebagai hasil belajar yang dibentuk dalam struktur kapasitas dan keterampilan yang dapat diperkirakan atau ditunjukkan melalui hasil dari pembelajaran (Mursid, 2021). Sedangkan Sabanna (2018) menyatakan hasil belajar merupakan kapasitas yang diperoleh seseorang setelah siklus pembelajaran terjadi, yang dapat memberikan perubahan dalam perilaku baik informasi, mendapatkan, perspektif maupun kemampuan siswa dengan tujuan agar menjadi lebih baik dari yang diharapkan oleh siapapun. Menurut Lestari (2020) hasil belajar adalah perubahan perilaku termasuk psikologis, penuh perasaan, sudut pandang psikomotorik setelah selesai memahami penggunaan model atau metodologi dan ditunjukkan dengan penilaian yang memunculkan jenis kualitas dalam jenis angka, huruf, atau tertentu. gambar diselesaikan oleh sekolah.

Dari definisi di atas, penulis berpendapat bahwa yang dimaksud dengan hasil belajar adalah kemampuan dan kapasitas siswa karena latihan pembelajaran yang ditampilkan sebagai informasi dan kemampuan siswa. Kejadian yang sering dijumpai dalam pembelajaran bahasa Inggris seperti keadaan siswa kurang aktif, tidak berpartisipasi, serta kurang inisiatif. Tidak ada pertanyaan dari siswa, gagasan maupun pendapat serta siswa kurang aktif di dalam kelas, kadang-kadang guru dalam kegiatan pembelajaran hanya, menyampaikan ilmu pengetahuan secara searah, sedangkan murid hanya menerima, mencatat dan mengingat apa yang disampaikan guru.

Hal seperti ini akan menjadi permasalahan guru, sehingga guru harus mempunyai model pembelajaran yang menarik untuk memecahkan masalah tersebut. Model yang dipilih penulis untuk memecahkan masalah tersebut adalah model Snowball Throwing dimana menetapkan peserta didik sebagai siswa yang dinamis, inovatif, sehingga akan termotivasi untuk mempelajari bahasa Inggris dan diharapkan siswa mampu menguasai Bahasa Inggris baik 
pengetahuan dan ketrampilan secara maksimal yang pada akhirnya siswa akan mendapatkan nilai yang maksimal pula.

Suri (2017) dalam tulisannya menyatakan bahwa model Snowball Throwing adalah penemuan yang menggarisbawahi minat dinamis siswa secara berkelompok untuk mencapai tujuan bersama, dilakukan dengan menggunakan bahan kertas berisi soal yang dibentuk seperti bola lalu dilemparkan ke siswa yang berbeda. untuk dijawab.

Menurut Mursid (2021) Snowball Throwing adalah model pembelajaran yang memanfaatkan bola soal yang terbuat dari kertas yang digerakkan melingkar menyerupai bola Kemudian dilemparkan secara bergiliran di antara siswa yang berkumpul di kelas, model pembelajaran ini menggabungkan kemampuan metodologi dan interaksi yang terbuka dan integratif. Menurut Lestari (2020) Snowball Throwing merupakan model pembelajaran berkelompok dengan permainan bola dari kertas yang diremas menyerupai salju yang dilemparkan kepada siswa, dimana bola berisi pertanyaanpertanyaan yang harus dijawab oleh siswa yang mendapatkannya.

Dari permainan tersebut akan dibentuk pembelajaran yang menyenangkan dan mengajak siswa untuk lebih dinamis pada saat latihan pembelajaran berlangsung. Dari pendapat yang dikemukaan, penulis berpendapat bahwa pembelajaran Snowball Throwing adalah model pembelajaran yang mengurutkan siswa menjadi beberapa pertemuan, setiap bagian kelompok membuat penyelidikan di selembar kertas dan menyusunnya seperti bola, kemudian bola tersebut dilemparkan ke siswa yang berbeda dalam waktu yang telah ditentukan, kemudian setiap pemain pengganti menanggapi pertanyaan dari bola yang dia dapatkan.

Dari kegitan pembelajaran Bahasa Inggris yang dilakukan dengan model Snowball Throwing, Peneliti mempunyai tujuan dari penelitian ini yaitu mendeskripsikan peningkatan hasil belajar Bahasa Inggris kelas XII TKR A dengan model Snowball Throwing di SMK Negeri 1 Ponjong. Sedangkan dari Penelitian Tindakan Kelas yang dilakukan ini, penulis dapat mengambil manfaat bahwa model Snowball Throwing ini akan mendorong siswa untuk berperan aktif, fokus, mandiri serta rasa ingin mengertinya tinggi dalam belajar Bahasa Inggris, sehingga peserta didik dapat meningkatkan hasil belajarnya. Dapat menjadi pertimbangan bagi guru untuk memilih dan menerapkan model Snowball Throwing sebagai alternatif peningkatan hasil belajar siswa dalam pemecahan masalah dalam kesulitan belajar bahasa Inggris.

\section{Metode Penelitian}

Penulis melakukan Penelitian pada kelas XII TKR A di SMK Negeri 1 Ponjong. Pemilihan tempat tersebut karena penulis mengajar Bahasa Inggris di SMK tersebut. Kegiatan penelitian mulai dilaksanakan pada tanggal 16 Januari 2020 sampai tanggal, 30 April 2020. Penelitian Tindakan kelas (PTK) ialah tindakan yang dilakukan dengan sengaja diawali dengan perencanaan, pelaksanaan, observasi dan refleksi pada setiap kegiatan dengan keinginan untuk memperbaiki kondisi pembelajaran dan kualitas pendidikan atau pembelajaran. Menurut Suyitno (2018: 4) kegiatan PTK dengan model menyusun (arranging), aktivitas (acting), persepsi (memperhatikan), refleksi (merefleksikan).

PTK merupakan suatu persepsi tentang tindakan yang dilakukan oleh guru dalam pembelajaran bersama peserta didik di dalam suatu kelas. (Suharsimi, dkk, 2006: 3), Model dimulai dengan menyusun, bertindak, memperhatikan dan menilai, seperti refleksi dan respon. Menurut Kemmis dan Mc. Taggart (1988) PTK Ini ditandai sebagai tindakan refleksi diri yang dilakukan oleh anggota dalam lingkungan secara bersahabat untuk meningkatkan pemikiran dalam pembelajaran dan pada keadaan dimana latihan pembelajaran diselesaikan secara procedural dengan Kegiatan Eksplorasi. Tindakan yang dilakukan melalui tahapan sebagai berikut yakni perencanaan (planning), tindakan (action), pengamatan (observation), dan refleksi (reflection).

Sebelum menyelesaikan penelitian yang sesungguhnya, penulis menyebutkan fakta-fakta objektif yang mendasar untuk menentukan pelaksanaan pembelajaran Bahasa Inggris di kelas XII TKR A, mengenali masalah yang terjadi dan merencanakan solusi yang sesuai dengan berpikir kritis. Pada tahap observasi awal, penulis melakukan pengamatan proses pembelajaran di kelas XII TKR A, dan menganalisanya dengan cara berdiskusi dengan wali kelas TKR A, sebagai Observer. Observasi awal ini dilakukan pada hari Kamis, 6 Februari 2020 dengan diadakan pre-test diawal pembelajaran yang diikuti oleh 31 siswa. Pre-test ini digunakan untuk mengetahui tingkat pemahaman peserta didik tentang materi $\mathrm{KD}$ 3.27. Offering Help (Penawaran Jasa), dengan hasil sebagai berikut; hasil belajar siswa masih berbeda, sebagian siswa dapat nilai bagus, tapi masih banyak siswa yang mendapat nilai rendah, serta guru masih cenderung menggunakan metode ceramah dan teacher centre. 
Perencanaan tindakan siklus pertama, dimulai dengan menganalisis hasil observasi. Dari hasil pengamatan awal, penulis membuat rencana tindakan pemanfaatan model Snowball Throwing untuk peningkatan hasil belajar siswa kelas XII TKR A SMK Negeri 1 Ponjong.

Analisa masalah digunakan untuk mengatur aktivitas seperti rincian aktivitas, waktu dalam setiap siklus, penanda pencapaian, kenaikan sebagai akibat aktivitas, dan hal-hal lain yang diidentifikasi dengan pengaturan normal. Dalam melakukan pembelajaran dengan model Snowball Throwing. Observer memperhatikan dan mencatat hal-hal yang terjadi selama siklus aktivitas untuk memperoleh informasi yang lebih akurat. Kemudian refleksi dilakukan jika ditemukan kekurangan pada siklus yang lalu, yang dijadikan alasan untuk menyusun rencana kegiatan pada siklus berikutnya. Peneliti juga memanfaatkan prosedur dan bermacam-macam informasi sebagai instrumen soal (test). Selain itu, informasi yang dikumpulkan merupakan instrumen yang digunakan untuk mengumpulkan informasi untuk data Penelitian Tindakan Kelas. Selanjutnya upaya untuk meningkatkan hasil belajar siswa kelas XII TKR A SMK Negeri 1 Ponjong. Jika bentuknya tidak benar, maka dibuatlah rencana peningkatan pembelajaran untuk siklus berikutnya.

Strategi pengumpulan informasi dalam penelitian ini adalah teknik observasi dan dokumentasi. Pengamatan dibuat secara terstruktur, dimana kriteria yang akan diamati sudah disiapkan terlebih dahulu, dalam bentuk lembar pengamatan. Instrumen penelitian ini terdiri atas: (a) lembar observasi, dan (b) soal ulangan (post test). Untuk menentukan validitas content lembar observasi dilakukan dengan konsultasi ahli, dalam hal ini adalah pembimbing Penelitian Tindakan Kelas. Sedangkan soal ulangan menggunakan soal yang telah divalidasi oleh guru senior MGMP Bahasa Inggris Tingkat Sekolah SMK Negeri 1 Ponjong. Validitas konten digunakan untuk mengukur sejauh mana butirbutir instrumen dapat mengukur variabel yang akan diukur.

Analisis informasi dalam pemeriksaan ini terdiri dari dua macam analisis yaitu analisis kualitatif dan deskriptif kuantitatif. Data yang didapat dari pengamatan maupun pendapat kolaborator mengenai pembelajaran kooperatif yang telah dilaksanakan. Sedangkan analisi kuantitatif digunakan untuk memberikan garis besar peningkatan pembelajaran di kelas. Seperti untuk menentukan kemajuan hasil belajar peserta didik. Secara individu sudah sesuai dengan KKM yang diterapkan di SMK Negeri 1
Ponjong yaitu 75, maka dalam penelitian ini dikatakan berhasil apabila 70\% memenuhi KKM atau minimal 75.

\section{Hasil dan Pembahasan}

Aktivitas pembelajaran yang dilakukan dalam PTK ini berupa tindakan yang dilakukan oleh guru terhadap siswa termasuk kolaborasi antar siswa. Tindakan dalam PTK ini memberikan pengalaman belajar pada siswa, karena didorong oleh kebutuhan dan tujuan yang ingin dicapai, yaitu meningkatnya hasil belajar siswa, karena bertambahnya inspirasi dan latihan siswa dalam interaksi pembelajaran. Penerapan pembelajaran dengan model Snowball Throwing memberikan pengaruh positif bagi peserta didik meningkatkan hasil belajarnya. Dapat dilihat pada aktivitas pembelajaran siklus I, dimana kegiatan pembelajaran peserta didik berperan sebagai pelaksana kegiatan dalam pembelajaran, sedangkan guru berperan sebagai penonton dalam memperhatikan bagian-bagian penunjuk hasil belajar peserta didik dalam pembelajaran. Pelaksanaan kegiatan pertama, siswa diberikan video diskusi materi Offering Help kemudian diberikan tes verbal (tanya jawab) sehubungan dengan video yang dilihat dan didengar oleh peserta didik.

Setelah pemberian soal pre-test, guru menyampaikan materi tentang Offering Help dan pendidik mengarahkan evaluasi. Selanjutnya guru mengarahkan membagi siswa menjadi kelompok-kelompok kecil. Selain itu, guru menginstruksikan peserta didik untuk membuat pertanyaan yang disusun di selembar kertas, setelah menyelesaikan pertanyaan, pengajar memberikan kebebasan siswa untuk berfikir kreatif dalam membuat pertanyaan selanjutnya kertas di remas berbentuk bola, kemudian kertas yang berisi pertanyaan tersebut dilempar ke peserta didik lain sesuai arahan guru, maka peserta didik yang lain akan mendapatkan satu bola kertas yang berisi pertanyaan, kemudian peserta didik akan membuka untuk menjawab pertanyaan dan ditulis di atas kertas. Kemudian kertas ditutup dibuat seperti bola dilemparkan lagi dengan arahan guru, kepada peserta yang berbeda sehingga dapat memberikan respon yang berbeda. Hal sebaliknya yang dilakukan guru adalah memberikan jawaban untuk peserta didik dengan tujuan mengetahui kesalahan dan memperbaikinya.

Tindakan peserta didik berikutnya membuat pertukaran diidentifikasi dengan memberikan penjelasan dan meminta data yang diidentifikasi baik secara lisan dan tulis di kertas yang berbentuk bola tersebut. Kegiatan pembelajaran 
pada siklus I diperoleh hasil pembelajaran masih belum baik. masih banyak siswa yang belum fokus pada jam belajar. Hal tersebut dapat diatasi dengan bantuan observer di dalam kelas yang membantu mengendalikan kelas saat mengamati proses pembelajaran di dalam kelas.

Dari evaluasi dan tindakan refleksi dari siklus I maka pada siklus II guru dapat meningkatkan pembelajaran Bahasa inggris dengan guru lebih meningkatkan memberikan tindakan pembelajaran Bahasa Inggris melalui pendalaman materi Offering Help dan peningkatan kemampuan individu, guru meningkatkan tindakan pembelajaran dengan memberi banyak tanya jawab tentang materi Offering Help untuk meningkatkan kemampuan belajar individu siswa, guru memberikan reward kepada siswa yang bisa menjawab pertanyaan dengan benar dengan memberikan tambahan nilai pada nilai pengetahuan. Sehingga dengan pembelajaran yang lebih fokus dan perhatian lebih terhadap peserta didik pada siklus II maka dapat meningkatkan hasil belajar Bahasa Inggris peserta didik.

Hasil dari penelitian ini ditunjukkan pada siklus I penelitian dinyatakan masih belum berhasil karena terdapat $68 \%$ peserta didik mencapai nilai tuntas. Serta masih terdapat $32 \%$ peserta didik belum mendapat nilai tuntas, maka peneliti melanjutkan siklus ke II, dan diperoleh hasil peserta didik yang mendapatkan nilai tuntas terdapat $90 \%$ dan $10 \%$ peserta didik yang mendapat nilai belum tuntas, dengan persentase nilai ketuntasan peserta didik mengalami kenaikan 22\% ditunjukkan dari data siswa yang mendapat nilai tuntas dari siklus I terdapat $68 \%$ dan siklus II ada 90\%. Sedangkan persentase siswa yang mendapat nilai belum tuntas mengalami penurunan $22 \%$ ditunjukkan dengan data nilai siswa yang belum tuntas dari siklus I terdapat $32 \%$ dan siklus II ada 10\%. Dari data tersebut menunjukkan bahwa pada siklus II penelitian dinyatakan berhasil karena persentase ketuntasan peserta didik 90\% lebih dari 70\% dari batas minimum yang ditetapkan oleh peneliti Sehingga dapat disimpulkan bahwa model pembelajaran Snowball Throwing dapat meningkatkan hasil belajar Bahasa Inggris kelas XII TKR A di SMKN 1 Ponjong.

Hal ini juga sejalan dengan penelitian terdahulu yang dilakukan oleh Wahyem (2018) mengatakan bahwa hasil penelitian dengan menggunakan model pembelajaran Snowball Throwing telah meningkatkan hasil, hal itu di tunjukkan Pencapaian ketuntasan menunjukkan telah memenuhi kriteria ketuntasan minimal target $85 \%$ dengan nilai $>75$. Sehingga model pembelajaran melempar bola salju sudah dapat dilakukan untuk meningkatkan hasil belajar siswa. Penelitian juga dilakukan oleh Kusumawati, (2017). Hasil penelitian menunjukkan bahwa penggunaan model pembelajaran Snowball Throwing dapat mempengaruhi hasil belajar IPA kelas IV SDN Bondrang Ponorogo, dimana hasil estimasi normal kelas tes 83,23 dan kelas kontrol 71,47.

Hasil akhir dari pengujian ini adalah ada pengaruh pemanfaatan model pembelajaran berbantuan Snowball Throwing terhadap hasil belajar IPA siswa kelas IV SDN Bondrang Sawoo Area Ponorogo tahun ajaran 2016/2017. Penelitian juga dilakukan oleh Sabanna, R. (2018) Hasil penelitian menunjukkan setelah tertarik pada interaksi pembelajaran menggunakan model Snowball Throwing siswa ingin belajar, ditunjukkan hasil belajar telah berkembang setelah mengikuti pembelajaran dengan menggunakan model pembelajaran Snowball Throwing. Hal ini terlihat dari hasil belajar siswa pada tes dasar, siswa yang memenuhi KKM sebesar $1,32 \%$. Setelah pembelajaran dengan model Snowball Throwing pada siklus I hasil belajar $86,36 \%$ dan siklus berikutnya $90,90 \%$. Ini memiliki peningkatan sebesar $4,54 \%$ dan pada pengujian terakhir terjadi peningkatan sebesar $0,40 \%$ dengan hasil terakhir sebesar 91,30\%.

Sementara penulis dalam Penelitian Tindakan Kelas yang dilakukan, berhasil dengan baik ditunjukkan dengan hasil yang dapat dilihat pada tabel meningkatnya hasil belajar individu peserta didik dari siklus I dan siklus II yang di tampilkan pada tabel berikut.

Tabel 1. Ketuntasan hasil belajar siswa

\begin{tabular}{clcc}
\hline No & \multicolumn{1}{c}{ Keterangan } & Siklus I & Siklus II \\
\hline 1. & $\begin{array}{l}\text { Jumlah peserta } \\
\text { test }\end{array}$ & 31 orang & 31 orang \\
2. & $\begin{array}{l}\text { Banyak siswa } \\
\text { yang tuntas } \\
\text { Banyak siswa } \\
\text { yang belum }\end{array}$ & 21 orang & 28 orang \\
tuntas & 3 orang \\
4. & Rata-rata kelas & 71 & 78 \\
5. & $\begin{array}{l}\text { Persentase } \\
\text { siswa yang }\end{array}$ & $68 \%$ & $90 \%$ \\
tuntas (\%) & & \\
6. & $\begin{array}{l}\text { Persentase siswa } \\
\text { yang belum } \\
\text { tuntas (\%) }\end{array}$ & $32 \%$ & $10 \%$ \\
\hline
\end{tabular}

Dari tabel 1 yang disajikan di atas terdapat rata-rata Hasil belajar peserta didik pada siklus I dengan rata-rata 71 sedangkan persentase 
ketuntasan kelas $68 \%$ dimana terdapat 21 peserta didik yang mendapatkan nilai tuntas. Sementara Persentase yang nilainya belum tuntas $32 \%$, terdapat 10 peserta didik belum mendapatkan nilai tuntas. Pada siklus II diperoleh data persentase ketuntasan semakin meningkat menjadi 90\% dengan rata-rata kelas 78 dimana ada 28 siswa yang mendapat nilai tuntas, Sementara persentase peserta didik yang tidak tuntas menurun persentasenya menjadi $10 \%$, karena tinggal 3 peserta didik yang mendapat skor tidak memadai dalam siklus II. Sehingga pelaksanaan pembelajaran Bahasa Inggris dari tiap siklus mengalami peningkatan hasil belajar. Sehingga dari data tersebut, dapat dinyatakan bahwa Penelitian Tindakan Kelas yang dilakukan oleh penenulis dinyatakan berhasil.

\section{Simpulan dan Saran}

Peningkatan hasil belajar siswa pada mata pelajaran Bahasa Inggris KD 3.27 Offering Help dengan memanfaatkan model pembelajaran Snowball Throwing telah memberikan hasil yang dapat dirasakan langsung oleh peserta didik kelas XII TKR A dan bagi guru mata pelajaran Bahasa Inggris. Dimana hasil yang ditunjukkan dari penelitian diantaranya, pertama, peserta didik senang dan tertarik terhadap pembelajaran Bahasa Inggris, Hal ini diperlihatkan oleh para siswa yang semula bermalas-malasan dan tidak bersemangat untuk mengikuti pembelajaran Bahasa Inggris menjadi antusias dan aktif mengikuti proses pembelajaran. Kedua, peserta didik lebih dinamis saat belajar Bahasa Inggris. Dengan tujuan agar interaksi pembelajaran terlaksana dan hasil belajar yang tuntas. Ketiga peserta didik memiliki daya kreativitas yang tinggi dalam menggungkapkan ide dan gagasan dalam pembelajaran bahasa Inggris sehingga membuat pembelajaran lebih aktif dan menarik. Keempat peserta didik berani mempresentasikan hasil gagasan dan ide kepada guru dan temanteman lainnya di depan kelas.

Sehingga dari keberhasilan Penelitian Tindakan Kelas yang dilakukan tersebut, penulis menyarankan kepada para guru SMK Negeri 1 Ponjong untuk mencoba menerapkan pembelajaran model Snowball Throwing untuk meningkatkan hasil prestasi belajar siswa. Dengan model Snowball Throwing, peserta didik senantiasa akan besemangat dan aktif dalam kegiatan pembelajaran di dalam kelas.
Pembelajaran dengan model Snowball Throwing salah satu model pembelajaran untuk memecahkan masalah, keaktivan peserta didik di dalam kelas dan untuk meningkatkan hasil belajar peserta didik.

\section{Daftar Pustaka}

Undang-Undang Republik Indonesia Nomor 20 Tahun 2003 Tentang Sistem Pendidikan Nasional. (2003). Jakarta: CV Eko Jaya.

Djamarah, S. B. (1999). Psikologi Belajar. Jakarta: Rineka Cipta.

Gagne, R. M. (1984). Teori-Teori Belajar \& Pembelajaran. Jakarta: Erlangga.

Suyitno. (2018). Metodologi Penelitian Tindakan Kelas dan R\&D. Bandung: Alfabeta.

Mursid, K. B. (2021). Pengaruh Model Pembelajaran Cooperative Tipe Snowball Throwing Terhadap Hasil Belajar Siswa di MI Al-Mursyid Citeureup-Bogor. EduInovasi: Journal of Basic Educational Studies, 57-74.

Sabanna, R. (2018). Penerapan Model Pembelajaran Snowball Throwing untuk Meningkatkan Motivasi dan Hasil Belajar Siswa pada Materi Turunan di Kelas XI SMA Negeri 1 Gandapura. repository.arraniry.ac.id/id/eprint/5985/.

Suri, N. A. (2017). Penerapan Metode Snowball Throwing dengan Media Visual untuk Meningkatkan Prestasi Belajar Bahasa Inggris Peserta Didik Kelas 1 MI PLUS Walisongo Trenggalek. repo.iaintulungagung.ac.id/5609/.

Kusumawati, N. ((2017)). Pengaruh model pembelajaran kooperatif dengan snowball throwing terhadap hasil belajar IPA pada siswa kelas IV SDN Bondrang Kecamatan Sawoo Kabupaten Ponorogo. Jurnal Kependidikan Dasar Islam Berbasis Sains 2(1), 1-12.

Lestari, R. D. (2020). Pengaruh Model Pembelajaran Snowball Throwing Terhadap Minat dan Hasil Belajar Tematik Siswa MIN 2 Blitar. repo.iain-tulungagung.ac.id/16471/.

Wahyem, W. (2018). Peningkatan Hasil Belajar Ilmu Pengetahuan Sosial Siswa Kelas VI SD Tulung Melalui Model Pembelajaran Snowball Throwing. Ideguru: Jurnal Karya Ilmiah Guru, 3(2), 97-108. https://jurnaldikpora.jogjaprov.go.id/index.php/jurnalid eguru/article/view/61. 